\title{
Local Governments, Traditional Councils and Public Relations Practices in Ogun State, Nigeria: An Awareness Study
}

\author{
Joy OLABANJO, Oscar ODIBOH, Ernest NWOSU and Naomi NDUBUEZE
}

Department of Mass Communication, Covenant University, Ota, Nigeria

Correspondence should be addressed to: Oscar ODIBOH, odion.odiboh@covenantuniversity.edu.ng

Received date:29 April 2019; Accepted date:30 September 2019; Published date: 19 November 2019

Copyright (C) 2019. Joy OLABANJO, Oscar ODIBOH, Ernest NWOSU and Naomi NDUBUEZE. Distributed under Creative Commons CC-BY 4.0

\begin{abstract}
Activities of local governments and traditional councils have the greatest impact on millions of ordinary Nigerians. Normally, public relations should be a tool for communicating these actions to create public awareness. However, there are questions whether public relations tools are being applied successfully to create appropriate public awareness, mutual understanding and goodwill for third tier governance in Nigeria. Ogun State offers the strongest traditional and grassroots administrations, closest to the neighbouring Lagos, Nigeria's commercial capital city. This study examines public awareness and perception of the public relations practices of local government and traditional councils in Ogun State, Nigeria. It evaluates the extent and consequences of institutional and administrative public relations practices on the general public. Excellence theory is used as the foundational philosophy of the study. Quota sampling method is adopted using the survey design. Thus, a questionnaire is used to gather respondents' opinion; and the resultant data are processed with the Statistical Package for the Social Sciences. Key results show that citizens' awareness of public relations activities of local governments and traditional institutions is not outstanding but fair. Healthcare activities of local councils and coronation ceremonies of traditional councils are most popular. Though local governments are perceived as more active than traditional institutions, public relations tools have not meaningfully helped the peoples' awareness of the two grassroots administrations' activities. The study concludes that local governments and traditional councils should leverage more on the benefits of public relations; and recommends among others the adoption of Ward system of public relations activities.
\end{abstract}

Keywords: Public Relations, Local Government, Traditional Institutions, Government, Awareness

Cite this Article as: Joy OLABANJO, Oscar ODIBOH, Ernest NWOSU and Naomi NDUBUEZE (2019)," Local Governments, Traditional Councils and Public Relations Practices in Ogun State, Nigeria: An Awareness Study" Journal of EU Research in Business, Vol. 2019 (2019), Article ID 685615, DOI: 10.5171/2019.685615 


\section{Introduction}

Local government is the third tier of government, working with traditional institutions to bring development to the people at the grassroots. They strive to close the gap between the governed and government. According to Fadeyi (2009), the Nigerian federalism, like other federal systems of government all over the world, is characterized by diverse ethnic groups, languages, culture, political affiliation and struggles for political power. The need to cater for these diverse elements and ensure service delivery at the grassroots level necessitated the creation of local governments (Odiboh, Ezenagu \& Okuobeya, 2019).

Iyeh (2014) also stated that traditional institutions are still an integral part of every organized society. Apart from caring for the lowest level of the peoples' survival, traditional institutions are custodians of cultural norms and values. These norms and values have helped in sanitizing various societies both in the pre and post-colonial Nigeria. They also form the basis upon which traditional rulers exercised their act of governance, power, authority and influence on their subjects. (Olaniran 2013:120).

Nigeria's 1999 constitution stipulates the functions and powers of three levels of government in such a way that none can single headedly perform the functions of service delivery to the people. Therefore, cooperation and communication of action are necessary for governance (Fatile and Adejuwon, 2009:10; Odiboh, Ezenagu, \& Okuobeya, 2019). Other comments are in Odiboh and Ekanem, (2019), Odiboh, Salawu and Doghudje (2019), and Odiboh (2019a,2011). Traditional institutions are valuable support system to the local government because they could influence their subjects at the grassroots positively or negatively to either support a sitting government or to vote them out. Therefore, in order to have a continuously beneficial relationship with the people and to be able to communicate these developments with them, there is need for effective use of public relations at the local government level and the traditional level. Public relations is the management of relationships between an organisation and its publics for the purpose of achieving mutual understanding between all concerned (Johnson, 2016; Johnson \& Sheehan 2016; Salu, 1994).

According to Lee (1961), public relations at the local level helps to communicate good administrative performance for public appreciation. However, the government must first do a good job for the people; and thereafter, call attention to it. Lee explains that it is necessary for local governments to be sound and honest, if they are to earn the peoples' confidence, respect and support. There cannot be good local government without public awareness of their activities. Public relations involve listening to the voice of the people of the community (Ndubueze, Odiboh, Nwosu \& Olabanjo, 2019; Odiboh, 2019b, 2002). As noted by Ben, Roberts and Georgina (2014), the local government is a structure that provides for the goods and services needed by the people and also brings development and good governance to the local levels. This notwithstanding, development has not met public expectations at the grassroots level in Nigeria due to lack of accountability and transparency in the administration of local government in Nigeria (Nwosu, Odiboh, Olabanjo \& Ndubueze, 2019; Obiyan \& Amuwo, 2013; Adeyemi et. al, 2012). This study examines the role of public relations in projecting the performance of local governments and traditional councils to the grassroots public.

\section{Statement of the Problem}

The third tier of government in Nigeria, which is the focus of this study, is an administrative structure designed to bring government closer to the people. This translates to two-way communication that brings about dividends of governance and development. There are arguments whether the local governments have lived up to expectation. In spite of the country's enormous oil wealth, many local governments and chieftaincy domains operate in the midst of poverty, diseases, lack of good access roads, electricity, pipe- 
borne water and other infrastructural facilities, leading to high rate of rural-urban migration (Odiboh, Nwosu, Olabanjo \& Ndubueze 2019). However, some local and traditional councils are performing excellently but unable to separate themselves from the rest. As a corporate element of marketing communication (Odiboh \& Oladunjoye, 2019), public relations is used to connect institutions people and institutions. In the case of local governments and traditional councils, public relations tools are either unused or poorly used to create awareness and build mutually beneficial relationships with the people. This study looks at public awareness of the overall public relations activities of local governments and traditional councils in Nigeria.

\section{Objectives of the Study and Research Questions}

The study seeks to examine the public relations activities of local government councils and the traditional councils in Ogun State. It also seeks to unearth the public's awareness of these public relations activities. It would also analyse public perception of local government councils and traditional councils and ultimately highlight areas for improvement.

Based on these objectives, the following research questions will be answered:

A. What are the public relations activities of local government councils and traditional councils in Ogun State, Nigeria?

B. Are the publics of these institutions aware of their public relations activities?

C. What are public perceptions of the local government councils and the traditional councils?

D. What are the expected areas of improvement of public relations in the eyes of the people?

\section{Theoretical Framework}

Excellence theory of public relations forms the foundational framework of this study. It is about how organisations are better managed in their environments through public relations (Grunig, 1992). The theory explains that organisational value is created through public relations. Good relationship with strategic publics helps to develop and achieve organisational goals, reduce costs of negative publicity, and increase revenue by providing the right image for stakeholders' products and services (Grunig \& Grunig, 2008). The summary of the theory is that, to maximize value of public relations, organisations must identify strategic publics and build long-term relationship with them through symmetrical communication programs. In relation to this work, the excellence theory basically explains the relationship that exists between grassroots governments and the people; and how they can use public relations to strengthen these relationships excellently. Using the theory, long-term relationships between the government and the people become foreseeable and possible through practical two-way communication which in turn fosters a mutual understanding between them.

\section{Research Design and Methodology}

For the purpose of this study, survey method of data collection was used. Survey is the collection of information from a sample of individuals through their responses to questions (Check \& Schutt, 2012: 160). Survey allows the use of quantitative approaches to recruit participants, collect data and present resulting information (Omojola, Odiboh \& Amodu, 2018; Odiboh, et al. 2018; Odiboh, Adeyeye \& Ekanem 2018).

Based on the research questions, a questionnaire was drawn up to elicit public responses on awareness of public relations activities of local government and traditional councils in general terms. Specifically, the survey instrument offered open and close ended questions on applied public relations tools used to create awareness, build mutual understanding and goodwill between the people and grassroots administrations in Ogun State. Copies of the questionnaire were self-administered to the population size by the field assistants to the researcher. The State was purposely 
selected because it has the oldest traditional and administrative system of governance nearest to Lagos, the commercial capital of the country.

The sample size for this study is 250 respondents drawn from two local governments and two traditional institutions in Ogun state, Nigeria. Abeokuta South and Ado-Odo/Ota local governments were selected. Abeokuta South was selected because it is the capital city with its headquarters at Ake. Ado-Odo/Ota was chosen because it is the industrial and residential hub of the state. Selected traditional councils are the palaces of Alake of Ake (Abeokuta South Local Government Area) and Olota of Ota (Ado-Odo/Ota Local Government Area). The palaces were selected because the occupant traditional rulers are first class and the number one Kings (Oba) in the selected local government areas. Quota sampling technique used for selecting the local government areas and traditional institutions was applied in choosing the respondents for the survey. The need for informed responses to research questions necessitated the application of education demographics in the survey. Thus, three levels of education shared in quota, the 250 slots meant for the study. These are tertiary (100), secondary (100) and primary (50) totalling (125) for each of Abeokuta and Ado-Odo/Ota.

\section{Results}

Through frequencies and percentages, collected data were analysed and presented in tables using the Statistical Package of the Social Science (SPSS) software. The tables show respondents' awareness of the public relations activities of selected local government and traditional councils, their level of satisfaction (with the activities) and suggestions for improvement. Out of 250 copies of distributed questionnaire, 229 (91.6\%) were returned filled without any flaw. Twenty-one (21) rejected questionnaire copies represented $8.4 \%$ mortality rate of the instrument. This means that the study scored an excellent and acceptable response rate.

Respondents' awareness of local governments' programmes was the first poser of the questionnaire. Table 1 below shows the results obtained through the questionnaire.

Table 1: Awareness of Local Governments' programmes

\begin{tabular}{|c|c|c|c|c|c|}
\hline \multicolumn{2}{|c|}{} & Frequency & Percent & Valid Percent & Cumulative Percent \\
\hline \multirow{4}{*}{ Valid } & YES & 119 & 52.0 & 52.0 & 52.0 \\
\cline { 2 - 6 } & NO & 82 & 35.8 & 35.8 & 87.8 \\
\cline { 2 - 6 } & NOT SURE & 28 & 12.2 & 12.2 & 100.0 \\
\cline { 2 - 6 } & Total & 229 & 100.0 & 100.0 & \\
\hline
\end{tabular}

Out of 229 respondents, 119 which represents $52 \%$ of the respondents said they are aware of PR practices of local government councils; 82 respondents (35.8\%) affirmed that they are not aware of PR practices of local government councils.
Meanwhile, 28 respondents which represent $12.2 \%$ are not sure of the local governments' public practices. The above information illustrates that the majority of the respondents are conscious of PR practices of local government councils. 
Table 2: Awareness of Traditional Councils' programmes

\begin{tabular}{|c|c|c|c|c|c|}
\hline \multicolumn{2}{|c|}{} & Frequency & Percent & Valid Percent & Cumulative Percent \\
\hline \multirow{3}{*}{ Valid } & YES & 37 & 16.2 & 16.2 & 16.2 \\
\cline { 2 - 6 } & NO & 144 & 62.9 & 63.2 & 79.4 \\
\cline { 2 - 6 } & NOTSURE & 47 & 20.5 & 20.6 & 100.0 \\
\cline { 2 - 6 } & Total & 228 & 99.6 & 100.0 & \\
\hline Missing & System & 1 & .4 & & \\
\hline Total & & 229 & 100.0 & & \\
\hline
\end{tabular}

Out of 229 respondents, only 37 (16.2\%) of the respondents said they are aware of PR practices of the traditional councils. However, 144 respondents (62.9\%) affirmed that they are not aware of PR practices of the traditional councils; whilst
47 which represents $20.5 \%$ are not sure if the local government carries out any public practices at all. The above information illustrates that the majority of the respondents are not aware of PR practices in the traditional councils.

Table 3: Local government PR activities which the respondents are aware of

\begin{tabular}{|c|c|c|c|c|c|}
\hline & & Frequency & Percent & $\begin{array}{c}\text { Valid } \\
\text { Percent }\end{array}$ & $\begin{array}{c}\text { Cumulative } \\
\text { Percent }\end{array}$ \\
\hline \multirow{11}{*}{ Valid } & $\begin{array}{l}\text { Issuing ID Cards } \\
\text { Registration/Collection }\end{array}$ & 5 & 2.2 & 4.4 & 4.4 \\
\hline & Healthcare services & 23 & 10.0 & 20.4 & 24.8 \\
\hline & Sport Activities & 6 & 2.6 & 5.3 & 30.1 \\
\hline & Coronation & 3 & 1.3 & 2.7 & 32.7 \\
\hline & Levy and Tax Collection & 4 & 1.7 & 3.5 & 36.3 \\
\hline & $\begin{array}{l}\text { Youth Empowerment } \\
\text { Programmes }\end{array}$ & 21 & 9.2 & 18.6 & 54.9 \\
\hline & Public Service & 16 & 7.0 & 14.2 & 69.0 \\
\hline & Education & 10 & 4.4 & 8.8 & 77.9 \\
\hline & Agricultural Programmes & 16 & 7.0 & 14.2 & 92.0 \\
\hline & $\begin{array}{l}\text { Community Development } \\
\text { Programmes }\end{array}$ & 9 & 3.9 & 8.0 & 100.0 \\
\hline & Total & 113 & 49.3 & 100.0 & \\
\hline Missing & System & 116 & 50.7 & & \\
\hline \multicolumn{2}{|l|}{ Total } & 229 & 100.0 & & \\
\hline
\end{tabular}

This was an open-ended question where the respondents listed some of the local government PR programmes known to them. Table three above shows that $2.2 \%$ say one of the PR activities they are aware of is ID card registration and collection, $10.0 \%$ says it is healthcare, $2.6 \%$ said they are aware of sport activities, $1.3 \%$ said coronation, $1.7 \%$ said levy and tax collection, $9.2 \%$ of the respondents said youth empowerment programmes, $7.0 \%$ of the respondents said public service, $4.4 \%$ wrote education as one of the PR activities they are aware of, $7.0 \%$ stated agricultural 
programmes, $\quad 3.9 \%$ said community development programmes. Thus, healthcare (10\%), youth empowerment programme (9.2\%), agricultural programmes $(7 \%)$ and public service $(7 \%)$ are top four activities of the local government that the respondents mentioned. The table shows that half $(50.7 \%)$ of the respondents did not answer this question being unaware of any public relations activity of the Local Governments.

Table 4: PR activities of Traditional Councils which the respondents are aware of

\begin{tabular}{|l|l|r|r|r|r|}
\hline \multicolumn{2}{|c|}{} & Frequency & Percent & \multicolumn{1}{|c|}{$\begin{array}{c}\text { Valid } \\
\text { Percent }\end{array}$} & Cumulative Percent \\
\hline \multirow{5}{*}{} & settlement of disputes & 4 & 1.7 & 11.1 & 11.1 \\
\cline { 2 - 6 } & Coronation & 11 & 4.8 & 30.6 & 41.7 \\
\cline { 2 - 6 } & Festivals & 8 & 3.5 & 22.2 & 63.9 \\
\cline { 2 - 6 } & Security & 4 & 1.7 & 11.1 & 75.0 \\
\cline { 2 - 6 } & $\begin{array}{l}\text { Community } \\
\text { development }\end{array}$ & 9 & 3.9 & 25.0 & 100.0 \\
\cline { 2 - 6 } & Total & 36 & 15.7 & 100.0 & \\
\hline Missing & System & 193 & 84.3 & & \\
\hline Total & & 229 & 100.0 & & \\
\hline
\end{tabular}

This was also an open-ended question where the respondents listed some of the Traditional Councils' PR programmes known to them. Table 4 above indicates that $1.7 \%$ mentioned settlement of disputes, $4.8 \%$ said coronation, $3.5 \%$ cited festivals,
$1.7 \%$ said security, $3.9 \%$ said community development. The $84.3 \%$ which represents the majority of the respondents are unaware of the PR activities of the Traditional Councils. They did not answer the question.

Table 5: PR media used by the Local Governments

\begin{tabular}{|l|l|r|r|r|r|}
\hline \multicolumn{2}{|c|}{} & Frequency & Percent & $\begin{array}{c}\text { Valid } \\
\text { Percent }\end{array}$ & $\begin{array}{c}\text { Cumulative } \\
\text { Percent }\end{array}$ \\
\hline \multirow{5}{*}{} & Television & 20 & 8.7 & 17.4 & 17.4 \\
\cline { 2 - 6 } & Radio & 35 & 15.3 & 30.4 & 47.8 \\
\cline { 2 - 6 } & Newspaper & 20 & 8.7 & 17.4 & 65.2 \\
\cline { 2 - 6 } & Word of Mouth & 18 & 7.9 & 15.7 & 80.9 \\
\cline { 2 - 6 } & Facebook & 5 & 2.2 & 4.3 & 85.2 \\
\cline { 2 - 6 } & Press Conferences & 1 & .4 & .9 & 86.1 \\
\cline { 2 - 6 } & Seminars & 7 & 3.1 & 6.1 & 92.2 \\
\cline { 2 - 6 } & Billboards & 6 & 2.6 & 5.2 & 97.4 \\
\cline { 2 - 6 } & Friends & 3 & 1.3 & 2.6 & 100.0 \\
\cline { 2 - 6 } & Total & 115 & 50.2 & 100.0 & \\
\hline Missing & System & 229 & 100.0 & & \\
\hline Total & & & & & \\
\hline
\end{tabular}

Results on Table 5 above show that $8.7 \%$ of the respondents stated television as a medium through which they became aware of the local governments' PR activities; $15.3 \%$ mentioned radio, $8.7 \%$ cited newspapers. Word of Mouth was cited by $7.9 \%$ of the respondents, whilst $2.2 \%$ talked about Facebook, $0.4 \%$ mentioned press conferences, $3.1 \%$ through seminars,
$2.6 \%$ through billboards and $1.3 \%$ became aware through friends and family. Ahead of all other media, radio showed as the lead awareness medium as far as local government public relations' activities are concerned. However, about half (49.8\%) of the respondents did not answer the question. 
Table 6: PR media used by Traditional Councils

\begin{tabular}{|c|c|c|c|c|c|}
\hline & & Frequency & Percent & $\begin{array}{c}\text { Valid } \\
\text { Percent }\end{array}$ & Cumulative Percent \\
\hline \multirow{9}{*}{ Valid } & \begin{tabular}{|l|} 
Television \\
\end{tabular} & 2 & .9 & 4.8 & 4.8 \\
\hline & Radio & 16 & 7.0 & 38.1 & 42.9 \\
\hline & \begin{tabular}{|l} 
Newspaper \\
\end{tabular} & 5 & 2.2 & 11.9 & 54.8 \\
\hline & Word of Mouth & 9 & 3.9 & 21.4 & 76.2 \\
\hline & Instagram & 2 & .9 & 4.8 & 81.0 \\
\hline & Seminars & 1 & .4 & 2.4 & 83.3 \\
\hline & Billboards & 3 & 1.3 & 7.1 & 90.5 \\
\hline & \begin{tabular}{|l} 
Relatives \\
\end{tabular} & 4 & 1.7 & 9.5 & 100.0 \\
\hline & Total & 42 & 18.3 & 100.0 & \\
\hline Missing & System & 187 & 81.7 & & \\
\hline \multicolumn{2}{|l|}{ Total } & 229 & 100.0 & & \\
\hline
\end{tabular}

According to this table, $0.9 \%$ of the respondents mentioned television as the medium through which they became aware of the PR activities of the Traditional Councils, $7 \%$ mentioned radio, $2.2 \%$ said newspapers. Others are $3.9 \%$, word of mouth; $0.9 \%$, Instagram; $0.4 \%$, seminars;
$1.3 \%$, billboards; and $1.7 \%$ became aware through friends and family. Radio takes the lead among the media of respondents' awareness of Traditional Councils' public relations activities. However, a large majority $(81.7 \%)$ of the respondents did not answer this question.

Table 7: Frequency of Local Governments' PR activities

\begin{tabular}{|l|l|r|r|r|r|}
\hline \multicolumn{2}{|c|}{} & Frequency & Percent & $\begin{array}{c}\text { Valid } \\
\text { Percent }\end{array}$ & Cumulative Percent \\
\hline \multirow{4}{*}{ Valid } & Very Often & 12 & 5.2 & 10.1 & 10.1 \\
\cline { 2 - 6 } & Often & 86 & 37.6 & 72.3 & 82.4 \\
\cline { 2 - 7 } & Rarely & 20 & 8.7 & 16.8 & 99.2 \\
\cline { 2 - 7 } & None & 1 & .4 & .8 & 100.0 \\
\cline { 2 - 6 } & Total & 119 & 52.0 & 100.0 & \\
\hline Missing & System & 110 & 48.0 & & \\
\hline Total & 229 & 100.0 & & & \\
\hline
\end{tabular}

Table 7 above shows that $37.6 \%$ of the respondents affirmed that Local Governments carry out PR activities often, while $8.7 \%$ of the respondents stated that they rarely carry out public relations activities. Also, 5.2\% of the respondents stated that the local government carries out PR activities very often. However, $48 \%$ of the respondents did not answer this question. 
Table 8: Frequency of PR activities of traditional councils

\begin{tabular}{|l|l|r|r|r|r|}
\hline \multicolumn{2}{|c|}{} & Frequency & Percent & \multicolumn{1}{c|}{$\begin{array}{c}\text { Valid } \\
\text { Percent }\end{array}$} & Cumulative Percent \\
\hline \multirow{4}{*}{ Valid } & Very Often & 5 & 2.2 & 6.4 & 6.4 \\
\cline { 2 - 7 } & Often & 20 & 8.7 & 25.6 & 32.1 \\
\cline { 2 - 7 } & Rarely & 53 & 23.1 & 67.9 & 100.0 \\
\cline { 2 - 7 } & Total & 78 & 34.1 & 100.0 & \\
\hline Missing & System & 151 & 65.9 & & \\
\hline Total & 229 & 100.0 & & \\
\hline
\end{tabular}

Table 8 above shows that $2.2 \%$ of the respondents stated that Traditional Councils execute public relations activities very often, $8.7 \%$ said often and $23.1 \%$ said the traditional council rarely carries out PR activities. The table further reveals that 151 (65\%) of 229 respondents did not answer the question.

Table 9: Has PR helped respondents in thinking about Local Governments?

\begin{tabular}{|l|l|r|r|r|r|}
\hline \multicolumn{2}{|c|}{} & Frequency & Percent & Valid Percent & Cumulative Percent \\
\hline \multirow{4}{*}{ Valid } & YES & 49 & 21.4 & 41.2 & 41.2 \\
\cline { 2 - 6 } & NO & 50 & 21.8 & 42.0 & 83.2 \\
\cline { 2 - 6 } & NOT SURE & 20 & 8.7 & 16.8 & 100.0 \\
\cline { 2 - 6 } & Total & 119 & 52.0 & 100.0 & \\
\hline Missing & System & 110 & 48.0 & & \\
\hline Total & 229 & 100.0 & & & \\
\hline
\end{tabular}

According to Table 9, 21.4\% of the respondents agree that the public relations activities influenced their thinking about Local Government; $21.8 \%$ answered in the negative; whilst $8.7 \%$ said they are not sure. About half (48\%) of the respondents did not answer the question.

Table 10: Has PR helped the respondents' thinking about traditional councils?

\begin{tabular}{|l|l|r|r|r|r|}
\hline \multicolumn{2}{|c|}{} & Frequency & Percent & Valid Percent & $\begin{array}{c}\text { Cumulative } \\
\text { Percent }\end{array}$ \\
\hline \multirow{4}{*}{ Valid } & YES & 16 & 7.0 & 18.2 & 18.2 \\
\cline { 2 - 6 } & NO & 54 & 23.6 & 61.4 & 79.5 \\
\cline { 2 - 6 } & NOT SURE & 18 & 7.9 & 20.5 & 100.0 \\
\cline { 2 - 6 } & Total & 88 & 38.4 & 100.0 & \\
\hline Missing & System & 141 & 61.6 & & \\
\hline \multicolumn{2}{|l|}{ Total } & 229 & 100.0 & & \\
\hline
\end{tabular}

Table 10 reveals that, $7 \%$ of the respondents agree that the public relations activities influenced their thinking about the Traditional Councils; $23.6 \%$ answered in the negative; whilst $7.9 \%$ said they are not sure. Drawing from this result, it is clear that public relations activities did not influence the majority of the public in thinking about the Traditional Councils. This is affirmed by the Table's result which shows that $61.6 \%$ of the respondents did not answer the question. 
Table 11: Respondents' satisfaction with local governments' activities

\begin{tabular}{|l|l|r|r|r|r|}
\hline \multicolumn{2}{|c|}{} & Frequency & Percent & \multicolumn{1}{c|}{$\begin{array}{c}\text { Valid } \\
\text { Percent }\end{array}$} & $\begin{array}{c}\text { Cumulative } \\
\text { Percent }\end{array}$ \\
\hline \multirow{3}{*}{ Valid } & Yes & 57 & 24.9 & 50.9 & 50.9 \\
\cline { 2 - 6 } & No & 25 & 10.9 & 22.3 & 73.2 \\
\cline { 2 - 6 } & Not Sure & 30 & 13.1 & 26.8 & 100.0 \\
\cline { 2 - 6 } & Total & 112 & 48.9 & 100.0 & \\
\hline Missing & System & 117 & 51.1 & & \\
\hline Total & 229 & 100.0 & & \\
\hline
\end{tabular}

Table 11 shows whether the respondents are satisfied with the public relations activities of Local Government Councils. According to the table, $24.9 \%$ of the respondents are satisfied with the public relations activities of the local government,
$10.9 \%$ affirmed that they are not satisfied, while $13.1 \%$ of the respondents are not sure if they are satisfied. In addition to the 'unsure' respondents, about half (51.1\%) of the entire sample size did not answer the question.

Table 12: Respondents' satisfaction with traditional councils' activities

\begin{tabular}{|l|l|r|r|r|r|}
\hline \multicolumn{2}{|c|}{} & Frequency & Percent & $\begin{array}{c}\text { Valid } \\
\text { Percent }\end{array}$ & Cumulative Percent \\
\hline \multirow{4}{*}{ Valid } & YES & 17 & 7.4 & 16.8 & 16.8 \\
\cline { 2 - 7 } & NO & 49 & 21.4 & 48.5 & 65.3 \\
\cline { 2 - 7 } & NOTSURE & 35 & 15.3 & 34.7 & 100.0 \\
\cline { 2 - 7 } & Total & 101 & 44.1 & 100.0 & \\
\hline Missing & System & 128 & 55.9 & & \\
\hline Total & 229 & 100.0 & & & \\
\hline
\end{tabular}

According to table 12 results, $7.4 \%$ of the respondents are satisfied with the public relations activities of the Traditional Councils, $21.4 \%$ affirmed that they are not satisfied, while $15.3 \%$ of the respondents are not sure if they are satisfied. This result shows that the level of dissatisfaction with
Traditional Councils' public relations is quite high especially when the negative responses $(21 \%)$ are merged with the unsure ones $(15 \%)$. To show a higher level of dissatisfaction, more than half (55.9\%) of the respondents did not answer the question. 
Table 13: Whether the PR activities added to respondents' knowledge about Local Government Councils

\begin{tabular}{|l|l|r|r|r|r|}
\hline \multicolumn{2}{|c|}{} & Frequency & Percent & $\begin{array}{c}\text { Valid } \\
\text { Percent }\end{array}$ & $\begin{array}{c}\text { Cumulative } \\
\text { Percent }\end{array}$ \\
\hline \multirow{4}{*}{ Valid } & YES & 44 & 19.2 & 39.3 & 39.3 \\
\cline { 2 - 6 } & NO & 42 & 18.3 & 37.5 & 76.8 \\
\cline { 2 - 6 } & NOT SURE & 26 & 11.4 & 23.2 & 100.0 \\
\cline { 2 - 7 } & Total & 112 & 48.9 & 100.0 & \\
\hline Missing & System & 117 & 51.1 & & \\
\hline Total & 229 & 100.0 & & \\
\hline
\end{tabular}

Table 13 shows that $19.2 \%$ of the respondents affirmed that the PR activities have added to their knowledge about the Local Government Councils, but $18.3 \%$ answered in the negative. However, $11.4 \%$ were not sure if it has added to their knowledge. The table shows further that, half $(51.1 \%)$ of the respondents ignored this question.

Table 14: Whether the PR activities have added to respondents' knowledge about the Traditional Councils.

\begin{tabular}{|l|l|r|r|r|r|}
\hline \multicolumn{2}{|c|}{} & Frequency & Percent & $\begin{array}{c}\text { Valid } \\
\text { Percent }\end{array}$ & $\begin{array}{c}\text { Cumulative } \\
\text { Percent }\end{array}$ \\
\hline \multirow{4}{*}{ Valid } & YES & 19 & 8.3 & 18.8 & 18.8 \\
\cline { 2 - 6 } & NO & 57 & 24.9 & 56.4 & 75.2 \\
\cline { 2 - 6 } & NOT SURE & 25 & 10.9 & 24.8 & 100.0 \\
\cline { 2 - 6 } & Total & 101 & 44.1 & 100.0 & \\
\hline Missing & System & 128 & 55.9 & & \\
\hline Total & 229 & 100.0 & & \\
\hline
\end{tabular}

According to this Table, $8.3 \%$ respondents agreed that public relations activities added to their knowledge about the Traditional Councils. However, 24.9\% respondents align to say that the public relations activities did not contribute to what they know about the local government. Only $10.9 \%$ said they are not sure. This outcome supports the admission that PR activities did not add to respondents' knowledge about the local government; more so that $55.9 \%$ did not answer the question. 
Table 15: Public Relations activities which the respondents want local governments to focus on

\begin{tabular}{|c|c|c|c|c|c|}
\hline \multicolumn{2}{|c|}{} & Frequency & Percent & Valid Percent & $\begin{array}{c}\text { Cumulative } \\
\text { Percent }\end{array}$ \\
\hline \multirow{4}{*}{} & Education & 16 & 7.0 & 13.7 & 13.7 \\
\cline { 2 - 6 } & Youth Empowerment & 8 & 3.5 & 6.8 & 20.5 \\
\cline { 2 - 6 } & Security & 10 & 4.4 & 8.5 & 29.1 \\
\cline { 2 - 6 } & Agriculture & 11 & 4.8 & 9.4 & 38.5 \\
\cline { 2 - 6 } & Job Creation & 8 & 3.5 & 6.8 & 45.3 \\
\cline { 2 - 6 } & Healthcare & 10 & 4.4 & 8.5 & 53.8 \\
\cline { 2 - 6 } & Social Amenities & 19 & 8.3 & 16.2 & 70.1 \\
\cline { 2 - 6 } & Community Development & 18 & 7.9 & 15.4 & 85.5 \\
\cline { 2 - 6 } & Election & 9 & 3.9 & 7.7 & 93.2 \\
\cline { 2 - 6 } & Stopping Child Trafficking & 8 & 3.5 & 6.8 & 100.0 \\
\cline { 2 - 6 } & Total & 117 & 51.1 & 100.0 & \\
\hline Missing & System & 112 & 48.9 & & \\
\hline \multicolumn{1}{|c|}{} & Total & 229 & 100.0 & & \\
\hline
\end{tabular}

The respondents listed public relations activities which they would want the local governments to focus on. Results indicate that $7 \%$ mentioned education; $3.5 \%$, youth empowerment; $4.4 \%$, security; $4.8 \%$, agriculture; $3.5 \%$ job, creation; and $4.4 \%$, healthcare. Others are $8.3 \%$, social amenities; 7.9\%, community development; $3.9 \%$, election; and $3.5 \%$ said stopping child trafficking.

Table 16: Public Relations activities which the respondents want traditional councils to focus on

\begin{tabular}{|l|l|c|c|c|c|}
\hline \multicolumn{2}{|l|}{ Valid } & Frequency & Percent & $\begin{array}{c}\text { Valid } \\
\text { Percent }\end{array}$ & $\begin{array}{c}\text { Cumulative } \\
\text { Percent }\end{array}$ \\
\hline \multirow{5}{*}{} & Youth Empowerment & 5 & 2.2 & 10.9 & 10.9 \\
\cline { 2 - 6 } & Security & 5 & 2.2 & 10.9 & 21.7 \\
\cline { 2 - 6 } & Education & 8 & 3.5 & 17.4 & 39.1 \\
\cline { 2 - 6 } & Social Amenities & 4 & 1.7 & 8.7 & 47.8 \\
\cline { 2 - 6 } $\begin{array}{l}\text { Valid } \\
\text { Missing }\end{array}$ & $\begin{array}{l}\text { Promotion of Cultural } \\
\text { Heritage }\end{array}$ & 4 & 1.7 & 8.7 & 56.5 \\
\cline { 2 - 6 } & Healthcare & 7 & 3.1 & 15.2 & 71.7 \\
\cline { 2 - 6 } & Moral Support & 7 & 1.3 & 6.5 & 78.3 \\
\cline { 2 - 6 } & Community Support & 3 & 1.3 & 15.2 & 93.5 \\
\cline { 2 - 6 } & $\begin{array}{l}\text { Promotion of Traditional } \\
\text { Image }\end{array}$ & 3 & 20.1 & 100.0 & \\
\cline { 2 - 6 } & Total & 183 & 79.9 & & \\
\hline Total & System & & & & \\
\hline \multicolumn{2}{|l|}{} & & & & \\
\hline
\end{tabular}

This table shows the public relations activities which the respondents want traditional council to focus on. Results indicate that, $2.2 \%$ said youth empowerment; $2.2 \%$, security; $3.5 \%$, education; $1.7 \%$, social amenities; and $1.7 \%$ said promotion of cultural heritage. Other results are: $3.1 \%$, healthcare; $1.3 \%$, moral support; $3.1 \%$, community support; and $1.3 \%$, promotion of traditional image. 
Table 17: Areas of improvement in the delivery of the traditional councils' activities

\begin{tabular}{|l|l|r|r|r|r|}
\hline \multicolumn{1}{|c|}{} & Frequency & Percent & Valid Percent & \multicolumn{1}{c|}{$\begin{array}{c}\text { Cumulative } \\
\text { Percent }\end{array}$} \\
\hline \multirow{5}{*}{} & $\begin{array}{l}\text { Frequent Town Hall } \\
\text { Meetings }\end{array}$ & 9 & 3.9 & 26.5 & 26.5 \\
\cline { 2 - 6 } & Social Media & 3 & 1.3 & 8.8 & 14.7 \\
\cline { 2 - 6 } Valid & Traditional Media & 5 & 2.2 & 20.6 & 35.3 \\
\cline { 2 - 6 } & $\begin{array}{l}\text { More Public Awareness } \\
\text { Programmes }\end{array}$ & 7 & 3.1 & 29.4 & 70.6 \\
\cline { 2 - 6 } & Bulk Messaging & 10 & 4.4 & 100.0 & 100.0 \\
\cline { 2 - 6 } & Total & 34 & 14.8 & & \\
\cline { 2 - 6 } Missing & System & 195 & 85.2 & & \\
\hline Total & & 229 & 100.0 & & \\
\hline
\end{tabular}

Table 17 above shows the respondents' opinion concerning PR activities which traditional councils should improve. Accordingly, $3.9 \%$ of the respondents want traditional councils to convene town hall meetings more frequently; $1.3 \%$ mentioned the use of social media, $2.2 \%$ said use of traditional media should be improved; $3.1 \%$ highlighted public awareness programmes and $4.4 \%$ underlined the use of bulk SMS in information delivery of traditional councils' activities.

Table 18: Areas of improvement in the delivery of the local governments' activities

\begin{tabular}{|l|l|r|r|r|r|}
\hline \multicolumn{2}{|c|}{} & Frequency & Percent & Valid Percent & $\begin{array}{c}\text { Cumulative } \\
\text { Percent }\end{array}$ \\
\hline \multirow{5}{*}{} & Use of Social Media & 17 & 7.4 & 18.3 & 18.3 \\
\cline { 2 - 6 } & Public Sensitization & 21 & 9.2 & 22.6 & 40.9 \\
\cline { 2 - 6 } & Use of Traditional Media & 27 & 11.8 & 29 & 69.9 \\
\cline { 2 - 6 } & Use of Bulk SMS & 12 & 5.2 & 12.9 & 82.8 \\
\cline { 2 - 6 } & Inter-Personal Relationship & 10 & 4.4 & 10.8 & 93.5 \\
\cline { 2 - 6 } & Seeking Public Opinion & 4 & 1.7 & 4.3 & 97.8 \\
\cline { 2 - 6 } & Employment of more & 2 & .9 & 2.2 & 100.0 \\
\cline { 2 - 6 } & Qualified Staff & 93 & 40.6 & 100.0 & \\
\cline { 2 - 6 } & Total & 136 & 59.4 & & \\
\hline Missing & System & 229 & 100.0 & & \\
\hline Total & & & & & \\
\hline
\end{tabular}

According to Table 18 above, $7.4 \%$ of the respondents suggested the improvement in the use of social media in the delivery of local governments' PR activities; 9.2\% suggested improved public mobilization; $11.8 \%$ mentioned upgraded use of the traditional media; $5.2 \%$ recommended the use of bulk SMS; 4.4\% highlighted improved inter-personal relationships; $1.7 \%$ endorsed seeking of public opinion; and $0.9 \%$ suggested the employment of more qualified staff.

\section{Discussion of Findings}

In this section, the results above are discussed to give deeper meaning and understanding to the survey outcomes. Four research questions guiding this study are the basis for this discussion. Questions sought to unveil respondents' opinion about the public relations activities of Local Government Councils and Traditional Councils, their level of satisfaction with such activations, and the way forward for the grassroots institutions.

RESEARCH QUESTION 1: What are the public relations activities of the local government councils and the traditional councils?

According to the data generated from the questionnaire, the study indicated that the 
rate at which the local government and the traditional council carry out public relations activities is very low. Findings in this respect can be seen in table 3 and 4 respectively. The institutions' public relations activities easily identified by the respondents include: community development programmes, healthcare, youth empowerment, ID cards registration and collection, public service, settlement of disputes, festivals, coronation, security amongst others. Salient functions which the respondents could not recall are road construction and maintenance, wastewater drainage and environment upkeep (of local governments); and family dispute settlement, community development advocacy, and land oversight functions of traditional rulers. This suggests that the people are not paying adequate attention to the highly important public relations functions of the two institutions.

\section{RESEARCH QUESTION 2: Are the publics} aware of these public relations activities?

From the findings above, there is no doubt that the people are aware of the public relations activities of the two local institutions. Tables 1 and 2 comparatively show that public awareness of local governments' public relations activities is higher than their level of awareness of the traditional council's public relations activities. On table 1, out of 229 respondents, 119 which represents $52.0 \%$ of the respondents said they are aware of PR practices in the local government, 82 which represents $35.8 \%$ of the respondents affirmed that they are not aware of PR practices in the local government, while 28 which represents $12.2 \%$ are not sure if the local government carries out any public practices at all. The above information illustrates that the respondents are conscious of PR practices in the local government. On the other hand, table 2 shows that out of 229 respondents, only 37 which represents $16.2 \%$ of the respondents said they are aware of PR practices in the traditional council, 144 which represents $62.9 \%$ of the respondents affirmed that they are not aware of PR practices in the local government, while 47 which represents $20.5 \%$ are not sure if the local government carries out any public practices at all. The above information illustrates that the respondents are lowly aware of PR practices in the traditional councils.

RESEARCH QUESTION 3: What are the public's perception of the local government councils and the traditional councils?

Tables 9 and 10 show how the PR activities of the local government and the traditional council have shaped people's thinking about their existence. From the tables, it can be deduced that public relations activities influenced people's thinking about the local government. Contrarily, the respondents affirmed that the public relations activities of the traditional council haven't influenced their thinking in any way. This disparity of perception shows on Tables 11 and 12 where the majority of the respondents were satisfied with the activities of the local government but generally dissatisfied with the activities of the traditional councils.

However, positive perception of local governments' PR activities over that of traditional councils shows up only comparatively. The quantum of responses generally indicates that the PR activities of both councils are perceived as ineffective in influencing public thinking. For instance, an average of half of the respondents did not attempt answering (missing) questions treated on Tables 9, 10,11 and 12. This is in addition to many negative responses recorded on each of the four tables. If PR activities do not inform and influence public actions and decisions, then they have failed in achieving one of their major goals of building mutual relationship.

RESEARCH QUESTION 4: What are the areas of focus and improvement of public relations activities of the local government councils and the traditional councils?

Responses to this question are shown on Tables 15, 16, 17 and 18 respectively. There are areas of joint focus and zones of exclusive attention. The people want both local governments and traditional councils to jointly focus more on education, youth 
empowerment, security, healthcare, provision of social amenities and community development. Separately, local governments should focus more on agriculture, job creation, elections and stoppage of child trafficking; whilst traditional councils need to pay more attention to promotion of cultural heritage and traditional image as well as providing moral support for the people. Results of Tables 15 and 16 show that people question the performance of the local institutions in these specific areas. Respondents' disclosures on Tables 17 and 18 show their concerns more in the institutions' media usage than anything else. People believe that both councils need to improve their use of social and traditional media. They would want the institutions to apply bulk messaging (SMS) in information dissemination. Separately, the people want the custodians of tradition to convene more town hall meetings; whilst local councils should apply more of interpersonal relationships, seek public opinion more and employ more qualified staff.

\section{Conclusion}

Results of this study are both enlightening and instructive. Findings show clearly that:

1. Respondents' awareness of the public relations activities of the local government and traditional council is extremely low.

2. Public relations tools as currently applied by the institutions are inadequate for reaching target publics. Unreached people still lack access to these institutions' public relations programmes.

3. Either public relations failed local governments and traditional councils or the grassroots institutions failed to use and benefit from public relations appropriately. Either way, this study has opened new opportunities to correct the observed institutional wrongs.

Local Government Councils and Traditional Institutions particularly in Ogun State and in Nigeria generally will benefit from the results and analysis presented above.
Disconnection between the local institutions and the people which clearly shows in this study need to be considered by local rulers and leaders. Efforts should be made to appropriate the benefits of public relations and bridge the gap between the people and their indigenous rulers. This study concludes that the government needs to focus more on public relations at the local level in order to ensure grassroots development which public relations can bring about.

\section{Recommendations}

Based on the objectives, findings and conclusion of this study, the following recommendations suffice.

1. Grassroots governments need to create stronger bond with the people through effective and efficient use of public relations tools. Local Government wards and their elected Councillors should be used as a bridge between the people and the local rulers. Ward identity, recognition and participation should be ensured during all PR programmes of local governments and traditional councils. This ward networking and involvement will go a long way in ensuring the public relations tools are applied beneficially.

2. Public relations professionals should pay greater attention to the grassroots in order to cancel the deficits recorded by this study. Rather than jostling for consultancy businesses from corporate organisations and federal/state governments, public relations practitioners should work for local governments and traditional rulers. Large opportunities have been revealed by this study which professionals could take up.

3. Teachers and students of public relations should also focus more attention to the grassroots where so much has been revealed by this study for more contributions to knowledge. Local Government Public Relations should be propped up as an important aspect in the discipline's pedagogy. 


\section{Acknowledgement}

We appreciate the Covenant University Centre for Research, Innovation and Discovery (CUCRID) for the financial support for this publication.

\section{References}

1. Adeyemi, O., Akindele, S., Aluko, O. and Agesin, B. (2012) 'Institutionalizing The Culture of Accountability, in Local Government Administration in Nigeria,' African Journal of Political Science and International Relations, vol 6(4), pages 8191.

2. Constitution of the Federal Republic of Nigeria. (1979). [Retrieved 5 February 2019] Available: http://www.constitutionnet.org/vl/item/c onstitution-federal-republic-nigeria-1979.

3. Constitutional Conference Nigeria (1994/1995) [Retrieved 5 February 2019]. Available:

http://www.nairaland.com/977832/abach as-national-constitutional-conference1994-95.

4. Fadeyi, R. (2001), 'Local Government Chairmen sue 36 governors,' The Punch, pages 1-2. June 19.

5. Fatile, J O. and Adejuwon, K D. (2009), 'Local Government and Inter-Governmental Relations' in Odion Akhaine (ed.), Local Government Administration in Nigeria: Old and New Visions, Centre for Constitutionalism and Demilitarization, Lagos.

6. Iyeh, P. (2014) 'Reconsidering Place of Traditional Institutions under the Nigerian Constitution: A Comparative Analysis, Journal of Law, Policy and Globalization, Vol.31, 2014.

7. Johnson, J. (2016) Public Relations and Public Interest, Routledge, London.

8. Johnson, J. and Sheehan, M. (eds), (2016) Theory and Practice of Public Relations, $4^{\text {th }}$ Edition, Allen Unwin, London.
9. Lee, K J. (1961), 'Public Relations in Local Government,' World Conference of Local Governments Washington, D.C. June 15-20, 1961.

10.Ndubueze, N, Odiboh, O., Nwosu, E. and Olabanjo, J. (2019), 'Awareness and perception of public relations practices in public tertiary institutions in Nigeria' Proceedings of the $33^{\text {rd }}$ International Business Information Management Association (IBIMA), ISBN: 978-0-99985512-6, 10-11 April, 2019, Granada, Spain.

11.Nwosu, E., Odiboh, O, Ndubueze, N. and Olabanjo, J. (2019), 'Public awareness and perception of public relations activities in government agencies in Nigeria' Proceedings of the $33^{\text {rd }}$ International Business Information Management Association (IBIMA), ISBN: 978-0-99985512-6, 10-11 April, 2019, Granada, Spain.

12.0biyan, S. and Amuwo, K. (2013), Nigeria's Democratic Experience in the Fourth Republic since 1999: Policies and Politics, University Press of America, New York.

13.Odiboh, O O. (2011) A Philosophy of Marketing Communication: Through Gabriel Marcel's Theory of Intersubjectivity, VDM, Germany.

14.Odiboh, O, Salawu, A. and Doghudje, C. (eds.), (2019) Introduction to Philosophy of Mass Communication for Higher Institutions, Stirling Horden, Ibadan.

15.Odiboh, 0. (2019a), Marketology: A Philosophy of Marketing Communication for Students, Teachers and Professionals, Prolific, Lagos.

16.Odiboh, 0. (2019b), Integrated Marketing Communication in Nigeria, APCON, Lagos.

17.Odiboh, 0. (2002) Integrated Marketing Communication, APCON, Lagos.

18.Odiboh, O. and Ekanem, T. (2019). Mass Communication Book of Book Reviews Vol. 1, Academy Publishers, Germany. 
19.0diboh, O. and Oladunjoye, A. (2019), 'Application of integrated marketing communication tools for promoting computers in Nigeria' Proceedings of the $33^{\text {rd }}$ International Business Information Management Association (IBIMA), ISBN: 978-0-9998551-2-6, 10-11 April, 2019, Granada, Spain.

20.Odiboh, O., Adeyeye, B. and Ekanem, T. (2018), 'Awareness of e-transaction among consumers of indigenous herbal remedies in Ota, Nigeria: A case for e-herbals' Proceedings of the 4th International Conference on Information Management (ICIM2018), Oxford University, Oxford UK.

21.Odiboh, O., Ezenagu, A. and Okuobeya, V. (2019), 'Integrated marketing communication tools and facials consumers in Nigeria: Applications and connexions' Proceedings of the $33^{\text {rd }}$ International Business Information Management Association (IBIMA), ISBN: 978-0-99985512-6, 10-11 April, 2019, Granada, Spain.
22.Odiboh, O., Olonode, A., Adesina, E. and Yartey, D. (2018), 'Influence of ecommunication and digital culture on Nigeria's indigenous socio-cultural systems: A focus on Abeokuta and Ota, Nigeria' Proceedings of the 4th International Conference on Information Management (ICIM2018), Oxford University, Oxford UK.

23.Olaniran O. and Arigun, A. (2014) 'Traditional Rulers and Conflict Resolution; An Evaluation of the Pre and Post-Colonial Nigeria,' Online Journal of Research on Humanities and Social Science Vol.3 No 21, 2013, p.120.

24.Omojola, O., Odiboh, O. and Amodu, L. (2018) 'Opinions as colours: a visual analysis technique for modest focus group transcripts,' The Qualitative Report. Vol. 23 No 8.

25.Salu, A. (1994), Understanding Public Relations, Talkback Publishers, Lagos. 